DOI https://doi.org/10.36059/978-966-397-179-7/1-16

\title{
THE CRIMINAL LAW ASPECTS OF UKRAINIAN BORDER SECURITY PROVIDING
}

\section{Natalya Orlovska}

\section{INTRODUCTION}

Experts believe that the modern answer to the negative aspects of globalization is so-called "glocalization" - the process of various spheres of human existence reaction at the local levels to world globalization. In other words, "glocalization" presents itself a kind of effort to reduce the severity of the contradictions of international development in the regional and even bilateral plane. At the same time the role and importance of state borders which are intended, on the one hand, to divide different political and institutional systems, and on the other, to provide contact between different state entities, are growing.

In such circumstances the issues of border security are aggravated, since the contradictions of the country's development in international, regional and national aspects are most clearly revealed in the border space. Border security was constituted around the turn of the XX and XXI centuries ${ }^{1}$. And until its basic elements are not clearly outlined, it complicates accurate analysis and preparation of appropriate recommendations ${ }^{2}$.

However, even with the current development of these issues seems a narrowed approach in which the purpose of border security is to foresee the creation of favorable factors for the national interests at the border ${ }^{3}$. In our opinion, threats to the state border inviolability, to human rights and

${ }^{1}$ Kupriienko D.A. (2014) Osnovni poniattia ta katehorii u sferi zabezpechennia prykordonnoi bezpeky [Basic concepts and categories in the field of border security]. Zbirnyk naukovykh prats Natsionalnoi akademii Derzhavnoi prykordonnoi sluzhby Ukrainy. Seriia: Viiskovi ta tekhnichni nauky. №1. P.358.

${ }^{2}$ Halaniuk Ya.S. (2018) Napriamy vzaiemodii derzhavnoi prykordonnoi sluzhby Ukrainy $z$ orhanamy publichnoi vlady u sferi prykordonnoi bezpeky [Interaction directions of the State Border Guard Service of Ukraine with public authorities in the field of border security]. Visnyk NADU pry Prezydentovi Ukrainy (Seriia «Derzhavne upravlinnia»). №2. P.43.

3 Tsevelov O.Ie., Zhuk S.M. (2017) Aktualni pytannia zabezpechennia prykordonnoi bezpeky Ukrainy u systemi natsionalnoi bezpeky [Actual issues of border security of Ukraine in the national security system]. Investytsii: praktyka ta dosvid. №10. P.90. 
freedoms in the around border area affect the socio-political and economic situation in the country as a whole, testify to the emergence and certain tendencies of the development of negative phenomena nationwide. Accordingly, there is a direct dependence of the national security level on the solution of problems related to the definition and functioning of the state border, as well as ensuring its protection and defense, and the security of the peripheral (border) territories adjacent to it ${ }^{4}$.

Confirmation of this is the analysis of those threats that occur in the border area. By nature, that is, by influencing specific social relationships, these threats can be political, military, economic and the so like. However, in law manifestations, they are overwhelmingly criminal offenses. It is no coincidence that modern European border security strategies are aimed, inter alia, at ensuring a high level of security for citizens, creating an effective system of countering cross-border threats, above all for international terrorism and illegal migration ${ }^{5}$. Although such a wording refers to large-scale negative phenomena they are made up of specific manifestations - terrorist crimes, crimes related to illegal migration. This list can be continued, for example, through illegal smuggling of illicit items across the border.

Thus, studies of the criminal law aspects of Ukraine's border security are appropriate and timely, and are aimed at security issues resolving in the border area as well as in the field of national security as a whole.

\section{Border security as a object of criminal law defense}

If the threats to border security are overwhelmingly criminal ones the question of whether border security is classified as criminal law protection objects should be raised.

In Part 1 of Art. 1 of the Criminal Code of Ukraine the legislator captures the objects of criminal law protection - the most important social values which are the objects of systemic social relations. Their importance to society is so great that without criminal means it is impossible to reach a proper level of security against antisocial attacks.

4 Kupriienko D.A. (2014) Osnovni poniattia ta katehorii u sferi zabezpechennia prykordonnoi bezpeky [Basic concepts and categories in the field of border security]. Zbirnyk naukovykh prats Natsionalnoi akademii Derzhavnoi prykordonnoi sluzhby Ukrainy. Seriia: Viiskovi ta tekhnichni nauky. № 1. P. 358.

${ }^{5}$ Halaniuk Ya.S. (2018) Napriamy vzaiemodii derzhavnoi prykordonnoi sluzhby Ukrainy $z$ orhanamy publichnoi vlady u sferi prykordonnoi bezpeky [Interaction directions of the State Border Guard Service of Ukraine with public authorities in the field of border security]. Visnyk NADU pry Prezydentovi Ukrainy (Seriia «Derzhavne upravlinnia»). № 2. P. 43. 
Herewith in the criminal law of Ukraine there is no clear hierarchy of objects of criminal legal protection: neither the sequence of articles in the Criminal Code, nor the severity of the relevant norms sanctions give grounds for unambiguous conclusions on this.

At first sight border security is not related to the objects of criminal law protection, because it is not mentioned in the normative list which refers to human and citizen's rights and freedoms, property, public order and public security, environment, constitutional establishment of Ukraine, peace and security of humanity. However, firstly, this list is indicative one, and secondly, border security actually provides the proper level of realization and protection of these social values.

It seems that the current edition of Part 1 of Article 1 of the Criminal Code does not fully reflect the most important social relations and the scope of their criminal law protection. In particular, the norm does not mention national security emphasizing only on the constitutional establishment. But this does not even correspond to the content of Section I of the Special Part of the Criminal Code. In view of this it is possible to suggest an amendment to Part 1 of Article 1 of the Criminal Code with an indication on national security protection which part is a border security.

It should be agreed that the role of border security cannot be assessed using formal quantitative criteria. It has many immeasurable aspects related to the image of government and the state. Therefore, some experts consider it as a level of protection of the state territory from dangerous trans-border factors and conditions which presuppose, as a rule, a serious violation of the territorial integrity of the state and the established border regime ${ }^{6}$.

In this vision, the emphasis is on the state survey of border security. However, in the modern world the state is an important, even the main, but not the only subject of its compliance and providing.

A somewhat different approach involves an anthropocentric survey the protection of the territorial integrity and sovereignty of the state, all spheres of public life and human activity, rights and freedoms of citizens in the border area. It achieves timely detection, prevention, neutralization of real and potential internal and external threats and ensures the

${ }^{6}$ Kupriienko D.A. (2014) Osnovni poniattia ta katehorii u sferi zabezpechennia prykordonnoi bezpeky [Basic concepts and categories in the field of border security]. Zbirnyk naukovykh prats Natsionalnoi akademii Derzhavnoi prykordonnoi sluzhby Ukrainy. Seriia: Viiskovi ta tekhnichni nauky. №1. P.361. 
sustainable development of border areas, transparency of the state border for cross-border activities and travel of persons ${ }^{7}$.

Border security analysis in the context of a criminal law protection object can both be interpreted as complementary ones. The first focuses on the state's authority on border security; the second - on the volume of human rights and freedoms in the border area that can be realized with the proper level of border security. However, it is necessary to clarify that border security is only protected by criminal law when the threats are so dangerous that other legal instruments are insufficient.

We have already expressed the opinion that social values, which are protected by criminal law, can be classified according to the criterion of importance for participants of criminal legal relations:

if social value reflects a person's private interest then it may be attributed to private-public values;

when a person is "interested" in a particular value not in the private but in the general social plane (i.e. as a member of society) such value can be described as public-private.

In our view, border security can be attributed to public-private social values the significance of which is determined by the state's international legal obligations, by a strategy for the social system development ${ }^{8}$. And every member of society «takes advantage» of the opportunities provided by the achieved level of such common values realization. This is consistent with the understanding of criminal law as a sphere of coincidence between public and private interests.

In the professional literature it is emphasized that the content of border security includes prevention of illegal movement of various goods, cross-border crime, cybercrime, illegal migration, terrorism etc. ${ }^{9}$ However, modern border policy is not only a complex of political and legal measures aimed at combating crime in the border area with all political measures and legal means available in the arsenal of the state in

${ }^{7}$ Demianiuk Yu.A. (2012) Prykordonna bezpeka: kontseptualnyi pidkhid do definitsii poniattia [Border security: a conceptual approach to the notion definition]. Hileia: naukovyi visnyk : zb. nauk. prats / hol. red. V. M. Vashkevych. K.: VIRUAN. Vol. 67. P. 660.

8 Orlovska N.A. (2012) Sanktsii kryminalno-pravovykh norm: zasady ta pryntsypy formuvannia [Criminal law sanctions: bases and principles foundation]: dys... d-ra yuryd. nauk. Odesa. P.187.

9 Demianiuk Yu.A. (2012) Prykordonna bezpeka: kontseptualnyi pidkhid do definitsii poniattia [Border security: a conceptual approach to the notion definition]. Hileia: naukovyi visnyk : zb. nauk. prats / hol. red. V. M. Vashkevych. K.: VIRUAN. Vol. 67. P. 660. 
view of the main characteristics of the society in which such policy is implemented ${ }^{10}$.

The question should be addressed much wider. Border security makes sense to be understood as the systematic activities of state bodies, public institutions and individual citizens aimed at the reliable protection of national interests from external and internal threats that are manifested in the border area, and effective counteraction to them ${ }^{11}$.

If criminal law issues of border security are considered in this context it is obvious that without active support of the population the state risks to collapse of the law enforcement system as a whole or in certain areas, in particular. And border security is therefore a prime example.

In view of the above it can be concluded that the criminal law aspects of ensuring the border security of Ukraine are such issues:

systemic - understanding border security as a public-private value and object of criminal law protection;

substantive - peculiarities of criminal law understanding and prevention of socially dangerous manifestations that pose threats to border security;

institutional - criminal legal support for preventive activity in the field of border security and the possibility of criminal law to provide support for such activity by the population.

\section{Criminal threats to Ukraine's border security}

In order to consider the mentioned issues it is necessary to determine the scope of those concepts that create criminal threats to border security: in what sense should border area be understood for the territorial localization of border security specification;

what kinds of crimes pose a criminal threat to Ukraine's border security, whether they can be classified, whether there are grounds for isolating border crime /crime in the border area.

What is about the first remark it should be noted that the border area (in the border security context) is considered by scientists in a narrow

\footnotetext{
${ }^{10}$ Kuryliuk Yu.B. (2017) Deiaki suchasni kryminalno-pravovi ta kryminolohichni aspekty zabezpechennia prykordonnoi bezpeky derzhavy [Some current criminal and criminological aspects of state border security]. Prykarpatskyi yurydychnyi visnyk. №4. P.81.

11 Kupriienko D.A. (2014) Osnovni poniattia ta katehorii u sferi zabezpechennia prykordonnoi bezpeky [Basic concepts and categories in the field of border security]. Zbirnyk naukovykh prats Natsionalnoi akademii Derzhavnoi prykordonnoi sluzhby Ukrainy. Seriia: Viiskovi ta tekhnichni nauky. №1. P.362.
} 
and broad sense. In a narrow sense such area is limited directly by the state border and the controlled border area (region).

In a broad sense it is advisable to refer to the border area the state border, border territory, air and underwater environment within the border area, continental shelf, exclusive economic zone.

According to experts opinion it is exactly broad meaning of the "border area" paradigm has to become the basis for determining main concepts related to the corresponding type of national security ${ }^{12}$.

Thus, criminal threats to border security must be localized in the border area which should be understood in a broad sense. It is advisable to address the question that such localization is not limited within national border area. The border areas of neighboring countries have also to be taken into account.

Such vision takes place because the specificity of border security threats lies in the «multilateralism» of their sources located on both sides of the border. It is known, in particular, that in the event of a deterioration of the criminal situation in the adjacent territory the threats of violation of the state border are significantly increased; criminal groups whose activities are related to the violation of the state border have their «bases», partners and clients in the territory of neighboring countries, etc.

What is about the kinds of crimes that pose a criminal threat to Ukraine's border security and whether they can be classified it is appropriate to note the following.

In the professional literature, as a rule, there are lists of such crimes or phenomena the manifestations of which are criminal offenses. For example, Ya. Galanyuk (2018) speaks about international terrorism, illegal migration, transnational organized crime, proliferation of weapons of mass destruction, drug trafficking, etc. ${ }^{13}$ V. Zelka (2015) offers a much broader range of actions - from political (aimed at undermining

12 Zelka V.L. (2015) Obschaya harakteristika administrativno-pravovyih osnov gosudarstvennogo upravleniya obespecheniya natsionalnoy bezopasnosti v pogranichnoy sfere [General characteristics of the administrative and legal foundations of the state administration for ensuring national security in the border sphere]. Visegrad Journal on Human Rights. № 2. P. 111 .

${ }^{13}$ Halaniuk Ya.S. (2018) Napriamy vzaiemodii derzhavnoi prykordonnoi sluzhby Ukrainy z orhanamy publichnoi vlady u sferi prykordonnoi bezpeky [Interaction directions of the State Border Guard Service of Ukraine with public authorities in the field of border security]. Visnyk NADU pry Prezydentovi Ukrainy (Seriia «Derzhavne upravlinnia»). № 2. P. 46. 
the sovereignty and territorial integrity of Ukraine) to environmental (ecological) ones. At the same time these actions can be both related to violation of state border integrity, and to be performed in the territory of Ukraine (in the border band and border areas) ${ }^{14}$.

It seems that trying to list crimes as the threats to border security is enough difficult and inappropriate task. From our point of view a more productive way consists in ability to approach this issue comprehensively - depending on the specific nature of the corresponding crimes objective side (modus operandi) - whether they are related to the movement of goods / items / people across the state border, or that they occur in the border area of Ukraine. In other words, these threats can be localized directly at the border or take place in border areas simultaneously creating favorable conditions (economic, social, demographic, etc.) for immediate threats to border security.

They represent themselves a system of crimes among which the most significant part is formed by economic socially dangerous acts. The selfinterest component is dominant here - the focus is on obtaining criminal proceeds. Accordingly, this is illegal, but economic in nature activity. In addition, there are so-called «providing» crimes which include corruption, related to the creation of organized criminal structures, fictitious business, money laundering, etc. ${ }^{15}$

The core of criminality in border area consists from cross-border crimes:

on the one hand, such acts fall within the scope of crimes of a transnational nature (Part 2 of Article 3 of the United Nations Convention against Transnational Organized Crime);

on the other hand, the characteristic of cross-border crimes is the fact that the offender crosses the state border, moves certain persons, objects,

14 Zelka V.L. (2015) Obschaya harakteristika administrativno-pravovyih osnov gosudarstvennogo upravleniya obespecheniya natsionalnoy bezopasnosti v pogranichnoy sfere [General characteristics of the administrative and legal foundations of the state administration for ensuring national security in the border sphere]. Visegrad Journal on Human Rights. № 2. P. 114.

15 Orlovska N.A. (2016) Kontseptualni zasady uchasti hromadianskoho suspilstva $v$ zabezpechenni bezpeky derzhavnoho kordonu (kryminolohichnyi vymir) [The conceptual bases of civil society involvement in the state border security (criminological survey)]. Visnyk Natsionalnoi akademii Derzhavnoi prykordonnoi sluzhby Ukrainy. Seriia : Yurydychni nauky : elektron. nauk. vyd. Khmelnytskyi. URL: https://nadpsu.edu.ua/wpcontent/uploads/2018/11/visnik_1_2016_ur.pdf 
cargo and more across the border. According to S. Filippov (2019), as a specific feature of cross-border crimes can be considered violations of certain border regimes ${ }^{16}$.

Therefore, we are talking not only about crossing the border neighboring countries, for example, when crossing the border at an air border point is taking place.

An important issue regarding transnational / cross-border crime understanding is its recognition of criminal wrongdoing in those countries whose interests are affected by the act. The resolution of this issue is significantly complicated by the unequal attitude of legislators from different states to the same violation. In other words, it is so-called multiple criminalization - in order to be recognized cross-border crime must be criminalized in at least two countries.

Quite illustrative in this regard is the draft International Classification of Crimes for Statistical Purposes suggested by the United Nations Office on Drugs and Crime. In this project it is noted that the crime is a criminal offense or a violation of the restriction or requirements concerning behavior as defined by the national criminal legislation. Accordingly, the attribution of a crime to a cross-border is based on a description of the behavior, but not a legal specification ${ }^{17}$. Therefore, the presence of criminalization in at least one country should be considered a sign of a cross-border crime.

Thus, cross-border crime embodies local criminality, with locality signifying regional rather than national level. Cross-border crime reflects the socio-economic, political, demographic specificity of the territories on both sides of the border, its specificity is directly determined by the degree of «transparency» of the borders, by the organization of their protection $^{18}$.

${ }^{16}$ Filippov S.O. (2019) Kryminolohichni zasady protydii transkordonnii zlochynnosti [Criminological basics of combating cross-border crime]: avtoref. dys....d-ra yuryd. nauk. Dnipro. 43 p.

${ }^{17}$ International classification of crimes for statistical purposes.Principles - Structures Application.Draft.UNODC, 2014. P. 6, 8.

18 Orlovska N.A. (2018) Transkordonna zlochynnist: hlobalizatsiia chy hlokalizatsiia [Cross-border crime: globalization or glocalization]. Kryminalne pravo v umovakh hlobalizatsii: mater. Mizhnar. naukovo-prakt. konf. (Odesa, 25 travnia 2018 roku). Odesa. P. 46-48. 
In view of this it can be argued that there are grounds for isolating crime in the border area as a relatively independent type of criminal activity. This is determined by:

a localization of criminal activity in a specific space - border area;

an existence of a certain structure of such crime for which crossborder crime is a part;

a relatively limited range of crimes with an emphasis on economic cross-border offenses;

an organized character that is related to the economic nature of the criminal activity - it requires a long-term preparation, establishment of relations, in particular, in the territory of the neighboring state. Criminal groups on the state border in their activities resort to violence, launder huge sums of money, bribe officials, as well as harm and threaten the economic system of the state ${ }^{19}$.

Directly related to crime in the border area is the opposition to preventive action on the part of the border population. It means involving local residents in criminal practices, minimal willingness to actively cooperate with law enforcement, significant opportunities to evade social control at the expense of the border factor itself ${ }^{20}$. Local residents are an active participant in criminal schemes. Violation of customs rules, smuggling (in the criminal law sense), organization of illegal migration, other kinds of shadow economic activity, first of all, cross-border ones this is the most profitable area of employment for local residents ${ }^{21}$. Exactly from the local population representatives the organized criminal groups are being formed providing shady economic activity through

${ }^{19}$ Kuryliuk Yu.B. (2017) Deiaki suchasni kryminalno-pravovi ta kryminolohichni aspekty zabezpechennia prykordonnoi bezpeky derzhavy [Some current criminal and criminological aspects of state border security]. Prykarpatskyi yurydychnyi visnyk. №4. P.81.

${ }_{20}$ Orlovska N.A. (2017) Do pytannia zabezpechennia bezpekovoi skladovoi transkordonnoho spivrobitnytstva [On the issue of ensuring a secure component of cross-border cooperation]. Transkordonna spivpratsia: problemy ta shliakhy yikh vyrishennia: mater. II Rehionalnoho kruhloho stolu (Odesa, 28-29 veresnia 2017 roku). Kyiv: Natsionalna akademiia prokuratury Ukrainy. P.144-147.

${ }^{21}$ Orlovska N.A. (2016) Kontseptualni zasady uchasti hromadianskoho suspilstva $v$ zabezpechenni bezpeky derzhavnoho kordonu (kryminolohichnyi vymir) [The conceptual bases of civil society involvement in the state border security (criminological survey)]. Visnyk Natsionalnoi akademii Derzhavnoi prykordonnoi sluzhby Ukrainy. Seriia : Yurydychni nauky : elektron. nauk. vyd. Khmelnytskyi. URL: https://nadpsu.edu.ua/wp-content/uploads/2018/11/ visnik_1_2016_ur.pdf 
extra-economic coercion, violent (sometimes armed) confrontation with law enforcement and corruption schemes.

As an example we can analyze the statistics on those crimes where border guards and customs officers were become victims: for example, in 2014 - 183 border guards and 44 customs officers were injured in criminal offenses; in 2015 - 55 and 45; in 2016 - 52 and 39; in 2017 50 and 16; in 2018 - 43 and 17 respectively. It can be seen that the number of special victims is decreasing, but the public danger of individual crimes is not reduced (for example, the killing of government officials related to their official activities).

Thus, this opposition can be considered as a significant criminogenic factor, and in some cases it represents itself the criminal activity in the form of open resistance to law enforcement activities and is part of crime in the border area.

Having taken into account the above it can be concluded that the manifestations of crime in the border area are criminal threats to border security. At the same time, prevention of cross-border crime is one of the priority tasks of border areas development on both sides of the border.

\section{Criminal law aspects of border security institutional providing}

In the context of criminal aspects of institutional providing border security, first of all, it is necessary to identify those subjects whose activities are related to counteracting criminal threats - subjects of crime prevention. In our view, we can distinguish the state and non-state actors between them.

As in any security field it is precisely the public authorities that play a main role in ensuring border security. This is due to the fact that, first of all, border security is a component of Ukraine's national security and, accordingly, its security is the main task of the state; secondly, security is associated with the enforcement of compulsory measures, restrictions on human rights and freedoms what is impossible for non-state actors and requires state control.

Public authorities in the field of border security are law enforcement and other executive authorities. In this context it is possible to distinguish such subjects as:

general - those who carry out this activity throughout the country including at the border area (in particular, the National Police, the Security Service of Ukraine); 
special - their activities are directly related to border security and counteracting the relevant threats (State Border Guard Service of Ukraine).

Corresponding authority bodies set up to address specific issues of border security include, for example, the State Migration Service of Ukraine, the State Custom Service (new custom), etc.

Since it is a crime in the border area then is an obligatory component of preventive action to engage with counterparts in neighboring countries. The forms and methods of such interaction can be very diverse: information-analytical cooperation; operative-search and technical cooperation; cooperation in the field of search and return of stolen items; detention of perpetrators of crimes, etc. There is difficult to overestimate the importance of sharing information about the emergence of new ways and types of crime, about the features of crimes concealment, technologies and technical means used in their commission; short- and medium-term assessments of criminogenic situation in regions with complex operational situation, etc. ${ }^{22}$.

Civil society (a totality of non-state actors in the prevention of criminal threats) implements its participation in a number of forms institutional and non-institutional. From our point of view, there is no sense in talking about individual citizens in the field of border security providing because the scale of the tasks implies mass involvement of the population in combating crime. Therefore, in the context of the analysis of non-state actors it is advisable to consider only organized forms of citizen participation in the protection of the state border and public order at the border area.

Such public associations operate under the authority of state entities. However, subordination does not mean their secondary nature. As long as the population does not support preventive action then it is inappropriate to hope that only the efforts of state structures can provide border security. In view of the above it is possible to outline the limits of the criminal justice provision of border security in the institutional survey.

22 Orlovska N.A. (2017) Do pytannia zabezpechennia bezpekovoi skladovoi transkordonnoho spivrobitnytstva [On the issue of ensuring a secure component of cross-border cooperation]. Transkordonna spivpratsia: problemy ta shliakhy yikh vyrishennia: mater. II Rehionalnoho kruhloho stolu (Odesa, 28-29 veresnia 2017 roku). Kyiv: Natsionalna akademiia prokuratury Ukrainy. P. 147. 
First of all, in this context criminal law support of law enforcement activities should be considered. Traditionally it involves issues of execution of an order (Article 41 of the Criminal Code), performance of a special task for the prevention or disclosure of criminal activity of an organized group or criminal organization (Article 43 of the Criminal Code), as well as a group of norms aimed at protecting law enforcement officers as representatives of the state and the bearers of its authority, among which are Articles 342, 343, 345, 347, 348, 349 of the Criminal Code.

As for employees of other executive bodies involved in border security members of public formations for the protection of public order and the state border (citizens who perform public duties) then in order to ensure their activities the Criminal Code equals their criminal status to law enforcement officers, in part, provides for special rules (for example, Art. 350, 352 of the Criminal Code).

In our view, this context should be complemented by issues related to the prevention of corruption by officials, as the area of border security is fraught with numerous corruption risks. Accordingly, the criminal law aspects of border security must be supplemented by articles providing for criminal responsibility for crimes containing corruption (in the first place, Article 368, 368-5 of the Criminal Code).

The current situation in the sphere of law enforcement, including border security, raises questions about the presumption of lawfulness of actions and decisions of an official who is obliged to act only on the basis, within the powers and in the ways provided by the Constitution and laws of Ukraine ${ }^{23}$.

Indeed, the presumption of law enforcement officer lawfulness is true in many countries and is a usual social norm. However, along with this presumption there must be opportunities for effective judicial protection of human rights and freedoms. Only the court can evaluate the right or wrong of the law enforcement officer. It should be noted that law enforcement must be protected not only by special means, but also by law.

${ }^{23}$ Kyrbiatiev O.O. (2019) Kryminalno-pravovyi vymir problemy prezumptsii pravoty pratsivnykiv pravookhoronnykh orhaniv, yaki vykonuiut profesiini oboviazky [Criminal law survey of the presumption of correctness of law enforcement officers performing professional duties problem]. Naukovyi visnyk Dnipropetrovskoho derzhavnoho universytetu vnutrishnikh sprav. Vol. 1. P. 119. 
They must have the appropriate powers and the citizens are obliged to obey them. At the same time, this approach is justified and can only be favorable if the public is convinced that the police officer who is on duty only acts within the limits of authority and law, and is a professional capable of making quick decisions in a difficult and dangerous situation.

Thus, the criminal law aspects of border security institutional providing have to be analyzed in the context of the support of the activities of crime prevention subjects, both state and non-state. This refers not only to law enforcement agencies of special purpose (for example, SBGSU), but also to other law enforcement and executive authorities established to ensure border security. Of particular importance at this stage should be given to civil society institutions public associations involved in the protection of public order and the state border.

The Criminal Code of Ukraine contains an enough large number of rules that allow law enforcement agencies to provide border security by which established the criminal responsibility for counteracting and unlawfully influencing preventive actors in this field. At the same time, it is advisable to pay special attention to the anti-corruption policy and to address the issue of the presumption of the lawfulness of the enforcement officer and its correlation with the proper and effective judicial protection of human rights and freedoms.

\section{CONCLUSIONS}

The above points out that the criminal law aspects of Ukraine's border security studies are aimed at addressing security issues both in the border area and in the field of national security in general. Border security threats are overwhelmingly criminal by nature.

The criminal law aspects of Ukraine's border security include:

systemic issues (understanding of border security as a public-private value and object of criminal protection (as element of Ukraine's national security));

substantive issues (crimes in border area are criminal threats to border security; prevention of cross-border crime is one of the priority tasks of border development on both sides of the border);

institutional issues (the Criminal Code of Ukraine contains a large number of rules that allow law enforcement agencies to provide border security, which establishes criminal liability for counteracting and 
unlawfully influencing preventive actors in this field; but it is advisable to pay special attention to anti-corruption policy and address the issue of the presumption of law enforcement officer).

\section{SUMMARY}

The article is devoted to the issues of criminal law provision of Ukraine's border security at the present stage. It is concluded that the threats to border security are, in the vast majority, criminally illegal ones. There is argued the point of view that the criminal law aspects of Ukraine's border security include systemic, substantive and institutional issues.

Systemic issues present themselves understanding of border security as a public-private value and object of criminal law protection (as element of Ukraine's national security). Substantive issues suppose crimes in border area as criminal threats to border security. That is why prevention of cross-border crime is one of the priority tasks of border development on both sides of the border. Institutional issues should be considered with a special attention to anti-corruption policy and presumption of authority officer lawfulness problems.

Studies of the criminal law aspects of Ukraine's border security are aimed at security issues resolving in the border area as well as in the field of national security as a whole.

\section{REFERENCES}

1. Kupriienko D.A. (2014) Osnovni poniattia ta katehorii u sferi zabezpechennia prykordonnoi bezpeky [Basic concepts and categories in the field of border security]. Zbirnyk naukovykh prats Natsionalnoi akademii Derzhavnoi prykordonnoi sluzhby Ukrainy. Seriia: Viiskovi ta tekhnichni nauky. №1. P.357-368 (in Ukraine)

2. Halaniuk Ya.S. (2018) Napriamy vzaiemodii derzhavnoi prykordonnoi sluzhby Ukrainy $z$ orhanamy publichnoi vlady u sferi prykordonnoi bezpeky [Interaction directions of the State Border Guard Service of Ukraine with public authorities in the field of border security]. Visnyk NADU pry Prezydentovi Ukrainy (Seriia «Derzhavne upravlinnia»). № 2. P. 41-47 (in Ukraine)

3. Tsevelov O.Ie., Zhuk S.M. (2017) Aktualni pytannia zabezpechennia prykordonnoi bezpeky Ukrainy u systemi natsionalnoi bezpeky [Actual issues of border security of Ukraine in the national 
security system]. Investytsii: praktyka ta dosvid. №10. P.88-90 (in Ukraine)

4. Demianiuk Yu.A. (2012) Prykordonna bezpeka: kontseptualnyi pidkhid do definitsii poniattia [Border security: a conceptual approach to the notion definition]. Hileia: naukovyi visnyk : zb. nauk. prats / hol. red. V. M. Vashkevych. K.: VIRUAN. Vol.67. P. 656-661 (in Ukraine)

5. Orlovska N.A. (2012) Sanktsii kryminalno-pravovykh norm: zasady ta pryntsypy formuvannia [Criminal law sanctions: bases and principles foundation]: dys... d-ra yuryd. nauk. Odesa. 432 p. (in Ukraine)

6. Kuryliuk Yu.B. (2017) Deiaki suchasni kryminalno-pravovi ta kryminolohichni aspekty zabezpechennia prykordonnoi bezpeky derzhavy [Some current criminal and criminological aspects of state border security]. Prykarpatskyi yurydychnyi visnyk. № 4. P. 80-83 (in Ukraine)

7. Zelka V.L. (2015) Obschaya harakteristika administrativnopravovyih osnov gosudarstvennogo upravleniya obespecheniya natsionalnoy bezopasnosti v pogranichnoy sfere [General characteristics of the administrative and legal foundations of the state administration for ensuring national security in the border sphere]. Visegrad Journal on Human Rights. № 2. P. 110-116 (in Russian)

8. Orlovska N.A. (2016) Kontseptualni zasady uchasti hromadianskoho suspilstva $v$ zabezpechenni bezpeky derzhavnoho kordonu (kryminolohichnyi vymir) [The conceptual bases of civil society involvement in the state border security (criminological survey)]. Visnyk Natsionalnoi akademii Derzhavnoi prykordonnoi sluzhby Ukrainy. Seriia : Yurydychni nauky : elektron. nauk. vyd. Khmelnytskyi. URL: https://nadpsu.edu.ua/wp-content/uploads/2018/11/visnik_1_2016_ur.pdf (in Ukraine)

9. Filippov S.O. (2019) Kryminolohichni zasady protydii transkordonnii zlochynnosti [Criminological basics of combating crossborder crime]: avtoref. dys....d-ra yuryd. nauk. Dnipro. 43 p. (in Ukraine)

10. International classification of crimes for statistical purposes. Principles - Structures - Application. Draft. UNODC, 2014. 69 p. URL: http://qps.ru/qUztN

11. Orlovska N.A. (2018) Transkordonna zlochynnist: hlobalizatsiia chy hlokalizatsiia [Cross-border crime: globalization or glocalization]. 
Kryminalne pravo v umovakh hlobalizatsii: mater. Mizhnar. naukovoprakt. konf. (Odesa, 25 travnia 2018 roku). Odesa. P. 46-48 (in Ukraine)

12. Orlovska N.A. (2017) Do pytannia zabezpechennia bezpekovoi skladovoi transkordonnoho spivrobitnytstva [On the issue of ensuring a secure component of cross-border cooperation]. Transkordonna spivpratsia: problemy ta shliakhy yikh vyrishennia: mater. II Rehionalnoho kruhloho stolu (Odesa, 28-29 veresnia 2017 roku). Kyiv: Natsionalna akademiia prokuratury Ukrainy. P. 144-147 (in Ukraine)

13. Kyrbiatiev O.O. (2019) Kryminalno-pravovyi vymir problemy prezumptsii pravoty pratsivnykiv pravookhoronnykh orhaniv, yaki vykonuiut profesiini oboviazky [Criminal law survey of the presumption of correctness of law enforcement officers performing professional duties problem] Naukovyi visnyk Dnipropetrovskoho derzhavnoho universytetu vnutrishnikh sprav. Vol. 1. P. 114-121 (in Ukraine)

Natalya Orlovska, Doctor in Law, professor, Head of the Department of Criminal Law and Procedure, National Academy of the state Border Guard of Ukraine named after Bogdan Khmelnitsky 46 Schevchenko str., Khmelnitsky, Ukraine, 29001 ORCID ID: orcid.org/0000-0002-4400-560X 